ISSN: 2362-1303 (Paper) | elSSN: 2362-1311(Online)

JOURNAL OF ADVANCED ACADEMIC RESEARCH (JAAR) July 2016

\title{
Restricted opportunity: the missing point in Nepali migration- discourse
}

\section{Pralhad Karki ${ }^{1}$ \& Prof. K D Manandhar, Ph. D $^{2}$}

1; PhD Scholar, Mewar University, Rajasthan, India

Email: pralhad@kcc.edu.np

2; Tribhuvan University, Kathmandu, Nepal

Email: kamallazimpat@ hotmail.com

Corresponding Author

Pralhad Karki

Email: pralhad@kcc.edu.np

\begin{abstract}
Restricted opportunity is the key push-factor that compels Nepalis to leave home for job abroad. Yet it is not taken seriously in the Nepali migration-discourse. A general survey of literature of migration issues in Nepal reveals how the factor is sidelined by stakeholders of migration particularly policy makers and those who are responsible for managing the foreign employment sector. Scholars are mostly found not emphasizing the point in their academic rhetoric on migration issues. Because of this there is a trend to surround migration discussion with two themes - remittance and labor-export. Although the themes are important and relevant, they alone cannot make the migration discourse complete. Due attention should therefore be given to the restricted opportunity and all components attached to it.
\end{abstract}

\section{Introduction}

The current discourse on migration in Nepal is dominated by what is generally termed as remittance and foreign employment. The government and financial institutions talk migration from the view point of remittance while those who are on job or are seeking one discuss migration from the angle of work abroad. Because of this the rhetoric on migration in the country is being structured only on two pillars: receipt of money (remittance) and labor-export. The mechanism of sending money from the foreign countries and receiving the same in various parts of Nepal is well established; the task of earning commission- money through this has also emerged as another lucrative profession. Similarly a number of manpower companies have been set up for managing the flood of Nepalis going abroad for job; their presence could compete with any industrial cum business complex. 


\section{JOURNAL OF ADVANCED ACADEMIC RESEARCH (JAAR) July 2016}

Policy framers and decision makers have also been influenced by this and they look at migration basically from the two standpoints. While there is no harm, in the short run, in the tendency of regarding migration as a two-factor theme, there are risks in it in the long term. The reason why Nepalis go abroad for job should be analyzed for understanding the migration in the real sense of the term. Several factors including restricted opportunities Nepalis face at home play the key role in pushing Nepalis outside the country. Unless these are analyzed the phenomenon of migration cannot be understood in proper perspective. Migration experts also emphasize the need to look at the specific components of restricted opportunity for analyzing the phenomenon of migration. Their view is that poverty is the result of an environment marked by restricted opportunity and poverty; they both in turn trigger the migration.

\section{Methodology}

This write-up pursues a general approach to point out the need to discuss intensively the issue of restricted opportunity in the migration discourse in the country. It does not claim to be an empirical attempt to present a case of restricted opportunity in the discussion on migration. The write-up first makes an attempt to demonstrate how undermined a theme the restricted opportunity is in the migration discourse in the country. Then it applies a research tool questionnaire-survey - for mapping the concept of restricted opportunity among those who are at the grass-root level and want to migrate. It is followed by a discussion of how restricted opportunity was neglected as the two burning issues - free visa and free ticket and migration angle in viewing the quake victims - were discussed in recent times. A general scenario of how Nepalis seek to leave the country for job abroad is then structured. Finally a theoretical backdrop of the whole issue of restricted opportunity is presented.

\section{A glimpse of restricted opportunity at the grass-root level}

At the grass-root level restricted opportunity is taken as lack of any chance for the poor to join work or any economic activity through which income can be generated. To some it means absence of capital to invest for doing any productive work. To others it refers to social deprivation (a sort of social exclusion) which means non-connectivity with people who are capable of decision making.

People in general have developed a sense of restricted opportunity in their own vocabulary and refer to it in their own style as they discuss poverty and economic deprivation in family, community and among friends. Various components of restricted opportunity constructed by scholars also find space in their discussion. Notable among them are economic structural obstacles, discrimination, lack of capacities, vulnerability in meeting basic needs, lack of capital, unstable conditions, aspiration deficiency, disability to exit poverty cycle, inability to voice and 
ISSN: 2362-1303 (Paper) | elSSN: 2362-1311(Online)

\section{JOURNAL OF ADVANCED ACADEMIC RESEARCH (JAAR) July 2016}

lack of representation. They wish the foreign employment will give them an escape from this chain of restricted opportunity.

A 4-question survey was undertaken by the writer on Baishakh 6-8, 2072 among 90 people who were seeking ways to leave the country for jobs in foreign countries through the network of manpower companies in Kathmandu. The survey was done on the spot randomly. The purpose was to have a sense of the structure that the restricted opportunity has in the mindset of foreign employment seekers.

The survey indicated that the foreign employment seekers had the idea of what restricted opportunity refers to. (Table 1). They were also familiar with the linkage of restricted opportunity with the migration. (Table 2 ). Would be migrant workers expect the state and the private sector to play role in pulling down the obstacles of restricted opportunity. (Table 3). Majority of them were pushed to look for foreign employment because of restricted opportunity at the local level. (Table 4).

Although the scale of the survey cannot represent the national scenario, it gives a glimpse of how seriously the foreign employment seekers take restricted opportunity as the key factor in compelling them to leave the country. The survey points out the need to take the restricted opportunity seriously in migration discourse.

Table 1 Understanding of restricted opportunity

\begin{tabular}{|c|c|c|}
\hline Options & Frequency & $\%$ \\
\hline $\begin{array}{c}\text { No resource to engage in } \\
\text { economic activity }\end{array}$ & 9 & 23.3 \\
\hline $\begin{array}{c}\text { Absence of connectivity (source } \\
\text { force)to get job }\end{array}$ & 21 & 12.2 \\
\hline & 11 & 54.4 \\
\hline Social exclusion & 49 & \\
\hline All of the above & & \\
\hline
\end{tabular}

The figures in the above Table point out how majority of respondents (49\%) refer to restricted opportunity as a concept that indicates resourcelessness, absence of connectivity and social exclusion. 
ISSN: 2362-1303 (Paper) | elSSN: 2362-1311(Online)

JOURNAL OF ADVANCED ACADEMIC RESEARCH (JAAR) July 2016

Table 2 Linkage of restricted opportunity with migration

\begin{tabular}{|c|c|c|}
\hline Options & Frequency & $\%$ \\
\hline Direct & 63 & 70 \\
\hline indirect & 27 & 30 \\
\hline
\end{tabular}

The figures in the above Table clearly points out respondents' observation that migration has linkage with restricted opportunity.

Table 3 Who should act to open opportunity?

\begin{tabular}{|c|c|c|}
\hline Options & Frequency & $\%$ \\
\hline State & 46 & 51 \\
\hline Private sector & 20 & 22.2 \\
\hline Individual & 10 & 11.1 \\
\hline Civil society & 14 & 15.5 \\
\hline
\end{tabular}

The figures in the above Table indicate respondents' belief that the state and private sector should take initiative to undo the chain of restricted opportunity.

Table 4 Reason for attempting to join foreign employment

\begin{tabular}{|c|c|c|}
\hline Options & Frequency & $\%$ \\
\hline Individual interest & 5 & 5.5 \\
\hline Restricted opportunities & 63 & 70 \\
\hline Family pressure & 10 & 11.1 \\
\hline Demonstration effect & 12 & 13.3 \\
\hline
\end{tabular}


ISSN: 2362-1303 (Paper) | eISSN: 2362-1311(Online)

\section{JOURNAL OF ADVANCED ACADEMIC RESEARCH (JAAR) July 2016}

The above Table demonstrates that $70 \%$ seek foreign employment because of compulsion created by restricted opportunities.

\section{Sidelining restricted opportunity}

Two instances of recent times - free visa free ticket provision and the angle of migrationrhetoric in viewing the disastrous earthquake victims - could be taken as examples of how the issue of connectivity between the chain of poverty-restricted opportunity and migration does not attract attention in the country. In both cases surface issues of remittance and job abroad were emphasized. ${ }^{1}$

The issue of free visa and free ticket refers to a provision introduced for making migration costfree for workers. Although it is important and is motivated by benefitting the workers through not compelling them to pay for travel and entry into the job-country, it has not taken into consideration various dimensions of restricted opportunity which force people to migrate. It instead triggered a row between Nepal government and foreign employment agencies in July 2015 resulting in 18-day stoppage of their office-work. Manpower companies had until then charged huge amount of money from workers for ticket and visa. The new provision did not allow them to earn money by exploiting workers. The issue could have been better studied in the light of restricted opportunity. ${ }^{2}$

Similarly the restricted opportunity, which is continuing in areas of 14 districts where earthquake victims are currently suffering most from the after - effects of the disastrous 2015 quake, should have figured prominently in the assessment of post-disaster needs assessment ${ }^{3}$ and the scheme of reconstruction ${ }^{4}$. The quake-hit districts are incidentally the ones which send significant number of migrant workers. The 2011-census had shown 300,435 absentee population ( $6 \%$ of total population of 14 districts) in those districts; experts believe most of these are migrant workers. The districts are believed to be sending some $18 \%$ of total migrant workers every year whereas the districts receive $17 \%$ of total flow of remittance. ${ }^{5}$ The need assessment and scheme of reconstruction could be explained as professionally designed. However, they could not address the restricted opportunity properly. This could be termed as a gap which should be fulfilled in future through adequate measures.

\footnotetext{
${ }^{1}$ Statements given by Nepal Government, and Association of Foreign Employment Agencies printed in media, July $1-15,2015$

2 Interview with a migration expert on July 22, 2015

${ }^{3}$ National Planning Commission, Post Disaster Needs Assessment, Executive Summary, June, 2015

${ }^{4}$ Government of Nepal, Reconstruction Plan as mentioned in the annual budget, 2015

${ }^{5}$ A Research Paper on Migration and Resilience: Experiences from Nepal's 2015 Earthquake
} 


\section{JOURNAL OF ADVANCED ACADEMIC RESEARCH (JAAR) July 2016}

Various studies dealing with remittance, poverty in relation to Nepal appear to be looking at the impact of remittance on poverty in Nepal. They appear not deeply conscious of the need for analyzing the restricted opportunities of poverty theory for determining pre-migration and post-migration scenario. As for example, contemporary studies such as the Qatar Nepal Remittance Corridor, Experience with Nepali families with foreign remittance : evidence from the Nepal Living Standard Survey, The Effect of Male Migration on Employment Pattern of Women in Nepal, Labour Migration and Remittances in Nepal, Role of Remittance in Rural Poverty Reduction in Khilung Deurali VDC, Syangja, etc. have explored various aspects of the remittance and poverty. They have, however, not taken the component of restricted opportunities as significant in the whole process. ${ }^{6}$

It is important for Nepal to analyze remittances or migration in the backdrop of poverty in Nepal as a result of restricted opportunities. Its philosophical stand is anchored to the belief that poverty is in the system, not in the poor individual. In other words Nepali export of men and women is poverty-generated; Nepali receipt of remittance is also poverty-prompted. (Migrants' expressions and observations of remittance-senders, published in various media materials during 2010-12 indicate the same) All the factors - restricted opportunities, migration and remittance overlap in essence.

\section{The scenario}

A general scenario of how Nepalis leave the country for jobs abroad could be structured in the following way for constructing a backdrop of foreign employment seekers.

Nepali youths' dream today is to get a passport, have a foreign country's visa stamped in it, secure air-ticket and leave the country. The government- figure of 1,500 Nepalis going abroad for job every day stands witness to the fact. Most of those who leave are within the age-group of $15-59$, the period of life widely accepted as economically active ${ }^{7}$; the group covers $57 \%$ of Nepal-population which will reach 28.3 million in 2016 on the basis of 2011-census-projection.

At present 3.6 million Nepalis are currently engaged in jobs abroad. $74 \%$ of them are unskilled workers while $25 \%$ are semi-skilled and $1 \%$ skilled. ${ }^{8}$ The remittance these workers send constitutes important resource for Nepal; its contribution is equivalent to $25 \%$ of GDP. In the year 2012-13 Nepalis sent Rs. 434 billion to the country as remittance. It showed increasing trend in the following year. The growth trend continued even after the shocking effect of the deadly earthquake on April 25, 2015.

\footnotetext{
${ }^{6}$ Pralhad Karki, Exporting Nepalis, 2012, p.

${ }^{7}$ Ministry of Finance, Economic Survey 2014-15, p. 128

${ }^{8}$ Ibid
} 
ISSN: 2362-1303 (Paper) | elSSN: 2362-1311(Online)

JOURNAL OF ADVANCED ACADEMIC RESEARCH (JAAR) July 2016

\section{Theoretical background}

Scholars surveying Poverty/Remittance Literature feel there is room for discussing, in varied ways, the regime of poverty, migration and remittance and the relationship among or between them. One way to study them is under the banner of five theories of poverty. The theories as explained by Ted K. Bradshaw in his Research Paper Series refer to individual deficiencies, cultural belief systems that support subculture in poverty, political economic distortions, geographical disparities, and cumulative and circumstantial origins. In a sense the premises of Nepal-poverty could be studied through all the five theories.

A few have studied the poverty and remittance through the approach of either of the theories such as human capital theory and other relevant theories, including the permanent income hypothesis, culture of poverty theory, and dual labor market theory.

The 2001 World Development Report sought to study "Attacking Poverty," through additional theories, such as theories of empowerment and social capital. The World Development Report groups the causes of poverty into three main categories: (1) "lack of income and assets to attain basic necessities;" (2) "sense of voicelessness and powerlessness in the institutions of state and society;" and (3) "vulnerability to adverse shocks, linked to inability to cope with them" (p. 34), but does not provide a theory of poverty. (Wikipedia)

Sociologist Charles Lebeaux argued in 1963 that poverty, rather than merely a lack of money, was in fact the result of several complex, interrelated causes. "Poverty is not simply a matter of deficient income," Lebeaux explained. "It involves a reinforcing pattern of restricted opportunities, deficient community services, abnormal social pressures and predators, and defensive adaptations. Increased income alone is not sufficient to overcome brutalization, social isolation and narrow aspiration." ${ }^{9} 1$

Scholars have identified various factors that are instrumental in creating an environment of restricted opportunities which in turn intensify poverty in varied ways. The champions of progressive social theory believe that poverty is created by economic system, political mechanism, and social distortions (discriminations of various sorts). The system developed in such atmosphere leads to restricted opportunities for income and resources with which to achieve income and well being. They explain how social economic systems result in individual

${ }^{9}$ Lebeaux's article was originally published in the New Left journal New University Thought, but also appeared two years later in a collection of essays by liberal academics and intellectuals called Poverty in America. In the midst of Johnson's War on Poverty, the argument that poverty was about more than money - or, as was sometimes argued, wasn't even primarily about money - was common currency in both liberal and left-leaning circles. 
ISSN: 2362-1303 (Paper) | eISSN: 2362-1311(Online)

\section{JOURNAL OF ADVANCED ACADEMIC RESEARCH (JAAR) July 2016}

poverty situation. (Bradshaw, 2006) The capitalism in its economic system creates unemployment and keeps wages at low rate. (Marx) Social systems mediate everything in the society; it mediates opportunities. (Durkheim)

According to the paper of Bradshaw, "Much of the literature on poverty now suggests that the economic system is structured in such as way that poor people fall behind regardless of how competent they may be. Partly the problem is the fact that minimum wages do not allow single mothers or their families to be economically self sufficient (Jencks 1996:72). The problem of the working poor is increasingly seen as a wage problem linked to structural barriers preventing poor families from getting better jobs, complicated by limited numbers of jobs near workers and lack of growth in sectors supporting lower skilled jobs (Tobin 1994). Interestingly research is showing that the availability of jobs to low income people is about the same as it has been, but wages workers can expect from these jobs have fallen. Fringe benefits including health care and promotions have also become scarce for low skilled workers. These and related economic changes documented by Blank (1997) and Quigley (2003) show the way the system has created increasingly difficult problems for those who want to work."

Scholars talk of a parallel chain of restricted opportunities in the political system. They say there is a linkage between the wealth and power; there is correlation between wealth and decision making. This leads to a chain of exclusion of the poor; suppression of their voice; no room for representation and participation; no space for empowerment to claim the economic benefits and justice in the society. Discriminations of various sorts create yet another layer of restriction of opportunities. According to Bradshaw "A final broad category of system flaws associated with poverty relate to groups of people being given a social stigma because of race, gender disability, religion, or other groupings, leading them to have limited opportunities regardless of personal capabilities. No treatment of poverty can be complete without acknowledging that groups against which discrimination is practiced have limited opportunities regardless of legal protections. The process of gaining stronger rights for minorities in poverty is an ongoing one, for which legal initiatives and public policy reform must work with efforts to change public attitudes."

The lack of capacities among the poor is another reason why people are in the environment of poverty. The poor lack capacity because they do not get opportunities to learn skills and enhance capacity; this disables them to voice their displeasure and opt for change to exit poverty. Aspiration for change is closely related to the capacity and it is conditioned by social system particularly social life and interactions. That is why the better offs aspire more and their horizon of aspiration goes on expanding indefinitely. The poor suffer from aspiration deficiency. Because of their continued entanglement in the chain of poverty, their horizon of aspiration is 
ISSN: 2362-1303 (Paper) | elSSN: 2362-1311(Online)

\section{JOURNAL OF ADVANCED ACADEMIC RESEARCH (JAAR) July 2016}

compelled to be limited. This leads to their lasting confinement into poverty-trap. (Arjun Appadurai, 2004)

On the basis of the above arguments about the restricted opportunities as the cause of poverty, an inventory of factors that are instrumental in restricting opportunities could be constructed through the basis of qualitative methodology. (see Table below) The same could be used in structuring a scene of what makes Nepalis go abroad and dispatch remittances home. Most of them are inter-related. Either one of them or more of them or their cumulative impact creates in a frustrated individual Nepali a desire to go abroad for employment.

\section{Components of restricted opportunity}

\begin{tabular}{|l|l|l|l|l|}
\hline $\begin{array}{l}\text { Economic } \\
\text { structural } \\
\text { obstacles }\end{array}$ & Discrimination & Lack of capacities & $\begin{array}{l}\text { Vulnerability in } \\
\text { meeting basic } \\
\text { needs }\end{array}$ & Lack of capital \\
\hline $\begin{array}{l}\text { Unstable } \\
\text { conditions }\end{array}$ & $\begin{array}{l}\text { Aspiration } \\
\text { deficiency }\end{array}$ & $\begin{array}{l}\text { Disability to exit } \\
\text { poverty cycle }\end{array}$ & Inability to voice & $\begin{array}{l}\text { Lack op } \\
\text { representation }\end{array}$ \\
\hline
\end{tabular}

Job in foreign countries used to appear as a panacea decades ago and is continuing to be so today in 2012. That is why there is a passionate race in the country among youths for getting a passport, having a visa-stamp in it and flying out. The year-long rush in pass-port offices, embassies, manpower companies and airlines validate the point. Should there be any hitch in the process, the passion makes the youths so blind that they are ready to pursue any risk for going abroad. The risk, government officials confirm, ranges from illegal means, fake ways to immoral acts, the upshot of which has already been a headache for Nepal.

\section{Findings}


ISSN: 2362-1303 (Paper) | elSSN: 2362-1311(Online)

\section{JOURNAL OF ADVANCED ACADEMIC RESEARCH (JAAR) July 2016}

The key finding is: restricted opportunity is not given due importance in the migration discourse in Nepal. This trend has led to biased understanding of labour export of Nepal which in turn has resulted in flawed policies.

Another finding is remittance and labour export figures are important but they alone cannot explain the whole case of Nepalis in foreign employment or Nepalis seeking foreign employment.

Each component of restricted opportunity should be addressed for making the migration discourse a complete one.

\section{Conclusion}

The restricted opportunity is thus found missing in the general migration discourse in Nepal. Scholars, policy makers and all stakeholders related to foreign employment issues should try to fill in the gap for the issue plays key role in shaping the map of Nepal-remittance and labour export. All the ten components of restricted opportunity should be taken up properly and discussed adequately to address problems related to migration. Since they are inter-related they should be discussed both as individual component and collective whole. Unless this is done the discussion on the issue of migration will remain incomplete.

\section{References}

1. Appadurai, Arjun 2004

2. Bradshaw, Ted K., Theories of Poverty and Anti-poverty Programs in Community Development, Research Paper Series of Rural Poverty Research Center, University of Missouri, Columbia, USA

3. Central Bureau of Statistics, 2010

4. Economic Survey of Finance Ministy, Nepal Government, 2010-11

5. Gamage, Sarah, Exporting People Recruiting Remittances: A Development Strategy for El Salvador

6. Isaku Endo Gabi G Afram, The Qatar Nepal Remittance Corridor, 2008

7. Lebeaux, Charles, 1963

8. Regmi, Kamal, Role of Remittance in Rural Poverty Reduction in Khilung Deurali VDC, Syangja, 2007

9. Media Materials collection 2010-12

10. Michael Lokshin and Elena Glinskaya, The Effect of Male Migration on Employment Pattern of Women in Nepal, 2004

11. Observations made in Foreign Employment Seminar 2012

12. Media reports published in English dailies July 1-15, 2015 